\title{
Pollen tube development and competitive ability are impaired by disruption of a Shaker $\mathrm{K}^{+}$channel in Arabidopsis
}

\author{
Karine Mouline, ${ }^{1,4}$ Anne-Aliénor Véry, ${ }^{1,4}$ Frédéric Gaymard, ${ }^{1}$ Jossia Boucherez, ${ }^{1}$ Guillaume Pilot, ${ }^{1}$ \\ Martine Devic, ${ }^{2}$ David Bouchez, ${ }^{3}$ Jean-Baptiste Thibaud, ${ }^{1}$ and Hervé Sentenac ${ }^{1,5}$ \\ ${ }^{1}$ Biochimie et Physiologie Moléculaires des Plantes, UMR 5004, Agro-M/CNRS/INRA/UM2, F-34060 Montpellier Cedex 1, \\ France; ${ }^{2}$ Laboratoire Génome et Développement des Plantes, UMR 5096 CNRS/UMP, F-66860 Perpignan Cedex, France; \\ ${ }^{3}$ Station de Génétique et Amélioration des Plantes, INRA Centre de Versailles, F-78026 Versailles Cedex, France
}

Sexual reproduction in plants requires elongation of the pollen tube through the transmitting tissues toward the ovary. Tube growth rate is a major determinant of pollen competitive ability. We report that a $\mathrm{K}^{+}$channel of the Shaker family in Arabidopsis, SPIK, plays an important role in pollen tube development. SPIK was found to be specifically expressed in pollen. When SPIK was heterologously expressed in COS cells, its product formed hyperpolarization-activated $\mathrm{K}^{+}$channels. Disruption (T-DNA insertion) of the SPIK coding sequence strongly affected inwardly rectifying $\mathrm{K}^{+}$-channel activity in the pollen-grain plasma membrane. Measurements of membrane potential in growing pollen tubes yielded data compatible with a contribution of SPIK to $\mathrm{K}^{+}$influx. In vitro pollen germination assays were performed, revealing that the disruption results in impaired pollen tube growth. Analysis of the transmission rate of the disrupted allele in the progeny of heterozygous plants revealed a decrease in pollen competitive ability, the probability of fertilization by mutant pollen being $\sim 1.6$ times lower than that by wild-type pollen. The whole set of data supports the hypothesis that functional expression of SPIK plays a role in $\mathrm{K}^{+}$uptake in the growing pollen tube, and thereby in tube development and pollen competitive ability.

[Key Words: Pollen tube development; Shaker $\mathrm{K}^{+}$channel; Arabidopsis; T-DNA knockout mutant]

Received July 31, 2001; revised version accepted November 28, 2001.

In flowering plants, the male gametes reside in the pollen, which is deposited on the receptive surface of the pistil, the female reproductive organ. The pistil is an elongated organ within which three structures can be distinguished: an apical stigma that receives pollen, an ovary that contains the ovules, and a style that connects the stigma to the ovary. On a compatible stigma, the pollen grain germinates and extrudes a tube that elongates through the style to reach the ovary and enter an ovule, where the tube tip bursts, allowing release of the male gametes for fertilization. Rapid elongation of the pollen tube, over a distance of a few hundred micrometers to several centimeters, is therefore an essential process for the sexual reproduction of flowering plants (Wilhelmi and Preuss 1999). Many pollen tubes may grow in the same style toward a few ovules, leading to competition. Tube growth rate is therefore an important determinant of pollen competitive ability, which de-

\footnotetext{
${ }^{4}$ These authors contributed equally to this work.

${ }^{5}$ Corresponding author.

E-MAIL sentenac@ensam.inra.fr; FAX 33-499-61-29-30.

Article and publication are at http://www.genesdev.org/cgi/doi/10.1101/ $\operatorname{gad} .213902$.
}

scribes the reproductive success of a pollen grain (SariGorla and Frova 1997).

Several molecular mechanisms responsible for pollen recognition by the stigma, allowing compatible pollen hydration, germination, and development, have been recently identified (Wolters-Arts et al. 1998; Schopfer et al. 1999; Takasaki et al. 2000; Cabrillac et al. 2001). Progress has also been made in the identification of extracellular cues present in the transmitting tissue that allow tube guidance toward the ovules /Cheung et al. 1995; Franklin-Tong 1999a; Yang 1998; Wilhelmi and Preuss 1999; Lord 2000). A large set of data has been obtained, clearly showing that directed tip growth involves $\mathrm{Ca}^{2+}$ based signaling supported by $\mathrm{Ca}^{2+}$ influx at the growing tube tip (Holdaway-Clarke et al. 1997; Moutinho et al. 1998; Franklin-Tong 1999b; Li et al. 1999). Control of cytosolic $\mathrm{Ca}^{2+}$ concentration at the tube tip also plays a role in the modulation of the rate of pollen tube growth (Pierson et al. 1994; Franklin-Tong 1999b). The other mechanisms specifically controlling growth rate are still poorly documented, despite the importance of this function for pollen competitive ability.

$\mathrm{K}^{+}$uptake is required for tube growth. Here we report the first molecular identification of a pollen ion channel. 
Heterologously expressed in mammalian cells, or in situ on the pollen membrane, it behaves as an inward $\mathrm{K}^{+}$ channel. Disruption of the gene in Arabidopsis results in decreased pollen competitive ability.

\section{Results}

Molecular cloning of SPIK

A gene encoding a $\mathrm{K}^{+}$channel belonging to the Shaker family (Jan and Jan 1992; Zimmermann and Sentenac 1999) was initially identified in silico (in BAC F3N11, GenBank accession no. AC006053) by The Arabidopsis Genome Initiative (2000) and named AKT5 (Lacombe et al. 2000) or AKT6 (Mäser et al. 2001) on the sole basis of sequence information. In this work, six cDNAs were isolated by RACE-PCR, identifying the full-length ORF (EMBL AJ309323). The deduced polypeptide is 889 amino acids long, with a predicted molecular mass of 99 $\mathrm{kD}$. Expression studies and functional analyses (see below) led us to name the encoded polypeptide SPIK, for Shaker Pollen Inward $\underline{\mathrm{K}}^{+}$channel.

The plant Shaker channel family contains nine genes in Arabidopsis. Members of the Shaker superfamily are thought to share the structural design of the Drosophila Shaker gene products (Jan and Jan 1997). Shaker channels consist of four subunits arranged around a central pore (MacKinnon 1991; Jan and Jan 1997). The hydrophobic core region of each subunit shows six transmembrane segments, named S1 to S6. S4 is characterized by the presence of basic amino acids and acts as a voltage sensor. The pore-forming sequence ( 20 amino acids) is located between S5 and S6 and harbors a GYGD motif, the hallmark of highly $\mathrm{K}^{+}$-selective channels. Analysis of the SPIK deduced sequence (Fig. 1A) revealed the typical hydrophobic core of Shaker-type channels, with the positively charged S4 segment and the GYGD motif in the pore-forming domain (data not shown). Downstream from the channel hydrophobic core, a putative cyclic nucleotide-binding domain is present in SPIK, as in every plant Shaker channel identified up to now. This is followed by an ankyrin domain (Sentenac et al. 1992), as in six out of the nine Shaker channels identified in Arabidopsis, and a KHA domain (so-called because of its richness in hydrophobic and acidic amino acids; Ehrhardt et al. 1997), present in every plant Shaker channel (Fig. 1A). The ankyrin domain of plant Shaker channels has been hypothesized to play a role in tethering the channel to regulatory and/or cytoskeleton proteins (Sentenac et al. 1992; Cao et al. 1995). Evidence has been obtained indicating that the KHA domain plays a role in the channel tetramerization process (Daram et al. 1997) and/or in channel clustering in the membrane (Ehrhardt et al. 1997).

\section{Expression of SPIK gene in Arabidopsis}

Northern blot experiments revealed that SPIK expression is restricted to flower tissues (Fig. 1B). Localization

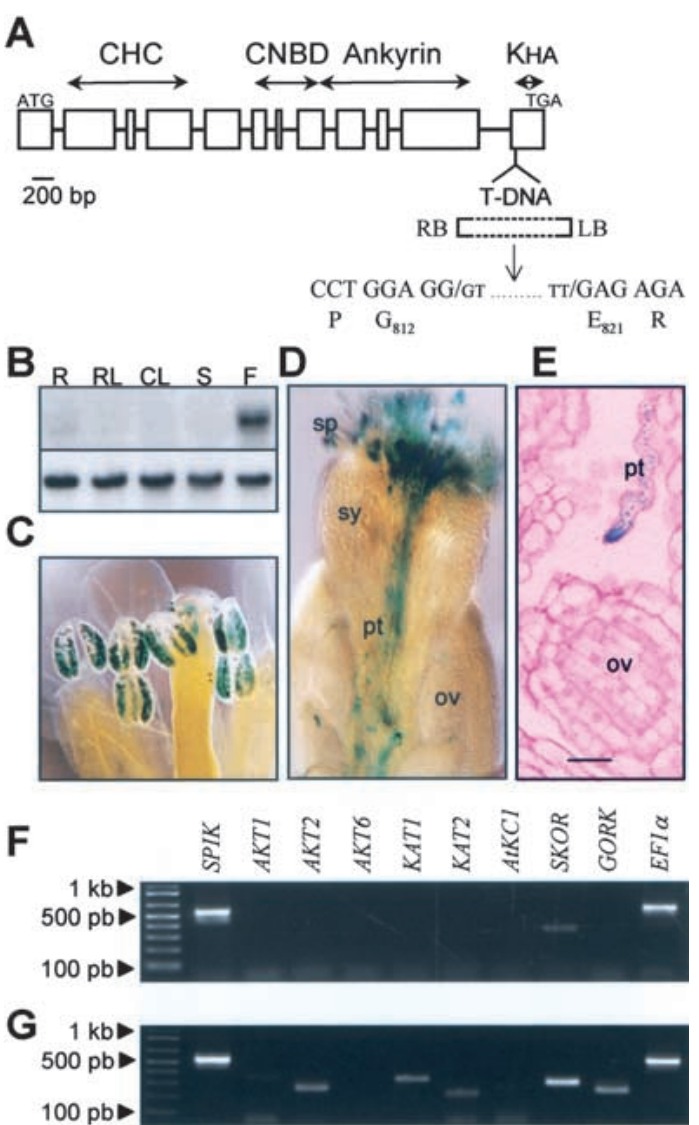

Figure 1. The Arabidopsis $\mathrm{K}^{+}$channel SPIK gene is specifically expressed in pollen. (A) SPIK gene structure. Boxes indicate exons. (CHC) Sequence encoding the channel hydrophobic core (six transmembrane segments and one pore domain); (CNBD, ankyrin, and $\mathrm{KHA}$ ) putative cyclic nucleotide-binding domain, ankyrin domain, and domain rich in hydrophobic and acidic residues, respectively. The insertion site of the disrupting $\mathrm{T}$ DNA in the spik-1 mutant is indicated. (LB and RB) Left and right borders of the T-DNA. (B) Northern blot analysis of SPIK expression. Total RNA was extracted from roots $(\mathrm{R})$, rosette leaves $(\mathrm{RL})$, caulinary leaves $(\mathrm{CL})$, stems $(\mathrm{S})$, or flowers $(\mathrm{F})$. The membrane was first hybridized with SPIK radioactive probe (upper autoradiogram) and thereafter with actin probe (control; lower autoradiogram). (C-E) Histochemical analysis of transgenic Arabidopsis expressing a SPIK::GUS reporter construct revealing GUS activity (blue staining) in pollen grains in anthers $(C)$, in pollen germinating on stigma $(D)$, and in pollen tubes (pt) growing through the style tissues toward the ovules (ov) $(D, E)$. (sp) Stigmatic papilla; (sy) style. E shows a longitudinal 0.3- $\mu \mathrm{m}$ thick cut of a stigma (bar, $25 \mu \mathrm{m}) .(F, G)$ RT-PCR experiments performed on total RNA extracted from pollen grains assessing the expression levels of SPIK and of the other members of the Arabidopsis Shaker gene family (AKT1, AKT2, AKT6, KAT1, KAT2, AtKC1, and SKOR: Lacombe et al. 2000; GORK: Ache et al. 2000). The EF1 $\alpha$ gene (Axelos et al. 1989) was used as control. Primers surrounding introns were used to discriminate amplification on genomic DNA. Reactions were stopped after 28, 30, $32,3436,38$, or 45 cycles, and an aliquot of the reaction medium was loaded on a $2 \%$ agarose gel. SPIK sequence amplification was almost maximal after 30 cycles. (F) Amplification after 30 cycles. $(G)$ Amplification after 45 cycles. In an independent experiment, another set of primers was used, leading to similar results (data not shown). 
of SPIK expression was further investigated using transgenic plants carrying the Escherichia coli $\beta$-glucuronidase gene (GUS) under the control of the SPIK promoter region $(2.5 \mathrm{~kb})$. GUS staining was detected in pollen only (Fig. 1C-E; no detectable staining in leaves, stems, roots, and root hairs; data not shown). Staining in pollen was detected both before and after germination: in pollen grains within anthers of flower buds or fully open flowers (Fig. 1C), and in pollen tubes growing toward the ovules, after pollen germination on the stigma (Fig. 1D,E). RT-PCR experiments performed on total RNA extracted from purified pollen grains suggested that SPIK is the member from the Shaker $\mathrm{K}^{+}$channel gene family displaying the highest expression level in pollen grain. Lower expression levels were suggested for the SKOR gene, which encodes an outwardly rectifying channel (Gaymard et al. 1998), and still lower for the other genes (Fig. 1F,G).

\section{Functional characterization of SPIK in a heterologous} system

In order to elucidate the physiological role of SPIK in pollen, the molecular function of the encoded polypeptide was investigated by expression in mammalian COS cells (Fig. 2). Electrophysiological analyses revealed that SPIK is a slowly activating, inwardly rectifying channel (Fig. 2A). This channel displayed a high selectivity for $\mathrm{K}^{+}$: comparison of whole-cell SPIK current $(I)$ at $-200 \mathrm{mV}$ in external solutions containing either $50 \mathrm{mM} \mathrm{KCl}$ or 50 mM XCl, with $\mathrm{X}^{+}$being $\mathrm{Na}^{+}, \mathrm{Li}^{+}, \mathrm{Rb}^{+}$, or $\mathrm{NH}_{4}{ }^{+}$, yielded $I_{\mathrm{X}} / I_{\mathrm{K}}=0.08 \pm 0.01(n=7), 0.06 \pm 0.03(n=6), 0.20 \pm 0.04$ $(n=5)$, or $0.18 \pm 0.04(n=4)($ mean $\pm S E)$, respectively. At an external $\mathrm{pH}$ of 6.0 , the channel half-maximal activation potential was $-205 \mathrm{mV}$. The channel activation was independent of the external $\mathrm{K}^{+}$concentration (Fig. 2B), but highly sensitive to external $\mathrm{pH}$, because acidification shifted the half-activation potential positively $1+47 \mathrm{mV}$ shift between $\mathrm{pH} 7.4$ and $\mathrm{pH}$ 5.0; Fig. 2B). Increasing the external $\mathrm{K}^{+}$concentration from $2 \mathrm{mM}$ to $150 \mathrm{mM}$ revealed a current saturation with an apparent $\mathrm{K}_{\mathrm{M}}$ of 14 $\mathrm{mM}$ (Fig. 2C). SPIK current was not sensitive to external $\mathrm{Ca}^{2+}$ in the range 1 to $10 \mathrm{mM}$ (data not shown), as previously reported for the inwardly rectifying $\mathrm{K}^{+}$current in Brassica or Arabidopsis pollen plasma membranes (Fan et al. 1999, 2001). It was blocked by $\mathrm{Cs}^{+}$, in an essentially voltage-independent way, with a current inhibition of $82 \% \pm 4 \%(n=7)$ in $10 \mathrm{mM} \mathrm{KCl}+50 \mathrm{mM} \mathrm{CsCl}$ (data not shown), and $90 \% \pm 2 \%(n=6)$ in $10 \mathrm{mM} \mathrm{KCl}+90 \mathrm{mM}$ $\mathrm{CsCl}$ (Fig. 2D). SPIK was identified at the single-channel level (cell-attached configuration; Hamill et al. 1981) on the basis of similarity with characteristics determined in the whole-cell configuration. Indeed, analysis of the most frequently observed channel (Fig. 2E) revealed activation kinetics and voltage dependence (threshold of activation and apparent gating charge $\mathrm{Zg}$ obtained from the Boltzmann fit; Fig. 2F) very similar to those of the whole-cell SPIK current (cf. Fig. 2B). The SPIK channel conductance was $\sim 14 \mathrm{pS}$ in $50 \mathrm{mM}$ external $\mathrm{K}^{+}$(Fig. 2G).

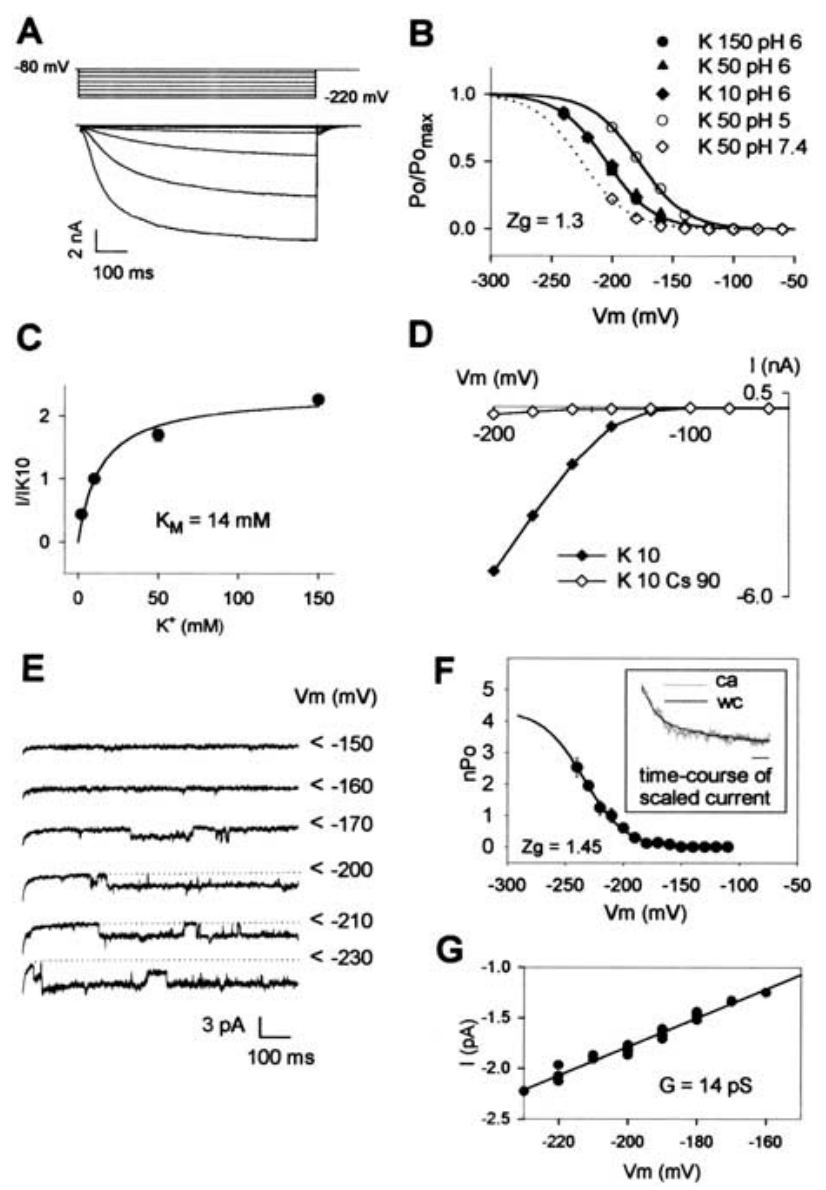

Figure 2. SPIK-mediated currents in COS cells. (A) Voltageclamp protocol and example of whole-cell currents in a COS cell expressing SPIK. External $\mathrm{K}^{+}$was $10 \mathrm{mM}$. (B) Analysis of SPIK activation at various external $\mathrm{K}^{+}$concentrations $(10,50$, or 150 $\mathrm{mM}$ at $\mathrm{pH} 6.0)$ and $\mathrm{pH}\left(5,6\right.$, or 7.4 in $\left.50 \mathrm{mM} \mathrm{K}^{+}\right)$. Lines are Boltzmann fits of the relative open probability $\left(\mathrm{Po} / \mathrm{Po}_{\max }\right)$ versus membrane potential. $(\mathrm{Zg})$ Equivalent gating charge obtained from the Boltzmann fit. Half activation potentials (from Boltzmann fit) are $-178 \mathrm{mV}(\mathrm{pH} 5.0),-205 \mathrm{mV}$ (pH 6.0), and $-226 \mathrm{mV}$ $(\mathrm{pH}$ 7.4). (C) Saturation of SPIK current with increased external $\left[\mathrm{K}^{+}\right]$. Currents were measured at $-200 \mathrm{mV}$. Data are means (normalized to the value obtained in $10 \mathrm{mM} \mathrm{K}^{+} \pm \mathrm{SE}(n=7)$. A Michaelis-Menten fit (solid line) gave an apparent $\mathrm{K}_{\mathrm{M}}$ of $14 \mathrm{mM}$. (D) Block of SPIK currents by cesium. External $\mathrm{K}^{+}$was $10 \mathrm{mM}$; added $\mathrm{Cs}^{+}$was $90 \mathrm{mM}$. Data shown are representative of five experiments. (E) Current traces recorded in the cell-attached configuration showing SPIK activity at the single-channel level. External $\mathrm{K}^{+}$concentration was $50 \mathrm{mM}$. The patch membrane potential (i.e., the measured cell resting potential, $-10 \mathrm{mV}$ in these conditions, minus the imposed pipette potential) is indicated at the right of current traces. The arrows indicate closed channel current levels. (F) SPIK single-channel activation features. The mean number of open channels $(\mathrm{nPo})$ was determined from 1-sec recordings $(n=7)$. The solid line is a Boltzmann fit of $\mathrm{nPo}$ versus the membrane potential. (Inset) Comparison of SPIK activation kinetics in whole-cell (wc) and cell-attached (ca) experiments. The holding and test potentials were $-80 \mathrm{mV}$ and $-220 \mathrm{mV}$, respectively. Seven single-channel recordings from the same patch were summed, yielding the ca trace that was scaled (in gray in the inset) to the wc trace (in black) for comparison. Inset, bar, $50 \mathrm{msec}$. $(G)$ Determination of SPIK unitary conductance in $50 \mathrm{mM}$ external $\mathrm{K}^{+}$. 
Disruption of SPIK coding sequence strongly affects inward $\mathrm{K}^{+}$-channel activity in the pollen-grain plasma membrane

A reverse genetic approach based on PCR screening of an insertion mutant library was developed to reveal the functions of the SPIK gene in the plant. An Arabidopsis mutant line, named spik-1, was identified by PCR screening of a collection of T-DNA-transformed plants (Bouchez et al. 1993). The T-DNA insertion (single locus and single copy, as indicated by Southern blot analysis; data not shown) was found to interrupt the last exon of the gene (Fig. 1A), just upstream of the KHA domain. To determine the effect of the spik-1 mutation on the plant phenotype, homozygous spik-1 mutant plants and heterozygous SPIK/spik-1 plants were grown in a growth chamber or in the greenhouse. Comparison with control wild-type plants grown in parallel in the same conditions did not reveal any obvious phenotype. The spik-1 plants were not found to be impaired in root hair development, excluding the hypothesis that SPIK could correspond to the gene identified by the tip 1 mutation affecting both root hair elongation and pollen tube growth (Schiefelbein et al. 1993). Finally, homozygous spik-1 plants generated as many seeds per silique as wild-type plants (data not shown).

Because SPIK is expressed in pollen, we tested the hypothesis that SPIK disruption could impair $\mathrm{K}^{+}$-channel activity in the pollen-grain membrane. SPIK currents were examined in native cells by patch-clamping pollengrain protoplasts. Whole-cell experiments on wild-type pollen protoplasts revealed both inward and outward currents (Fig. 3A). The inward current was dominated by a slowly activating component, appearing below a threshold potential of $\sim-100 \mathrm{mV}$, strongly reminiscent of that recorded in SPIK-expressing COS cells. Indeed, the activation kinetics and the steepness of $\mathrm{Po} / \mathrm{Po}_{\max }$ dependence on voltage (i.e., apparent gating charges $\mathrm{Zg}$, close to 1.3 in both cases) were similar (Fig. 3A). This inwardly rectifying current was highly selective for $\mathrm{K}^{+}$(against $\mathrm{Cl}^{-}$ and $\mathrm{Ca}^{2+}$; data not shown). Similar experiments were performed on protoplasts prepared from pollen grains obtained from homozygous spik-1 mutant plants. Remarkably, the inward $\mathrm{K}^{+}$current was strongly reduced, the slowly activating, inwardly rectifying component being no longer observed (Fig. 3B,C), providing evidence that SPIK was not expressed in a functional state in the spik-1 mutant pollen. Furthermore, these experiments suggested that SPIK provides the main pathway for $\mathrm{K}^{+}$uptake in these cells at hyperpolarized membrane potentials. Analysis of the remaining current (weakly rectifying) in spik-1 mutant pollen revealed a reversal potential close to the $\mathrm{K}^{+}$equilibrium potential (Fig. 3C), indicating that this background current was mainly carried by $\mathrm{K}^{+}$ ions.

To examine the possibility of SPIK involvement in wholesale $\mathrm{K}^{+}$uptake during tube growth, the resting membrane potential of young growing tubes $(\sim 100 \mu \mathrm{m}$ long) was investigated (Fig. 3D). Measurements were carried out in the presence of $1 \mathrm{mM}$ external $\mathrm{K}^{+}$. Recordings
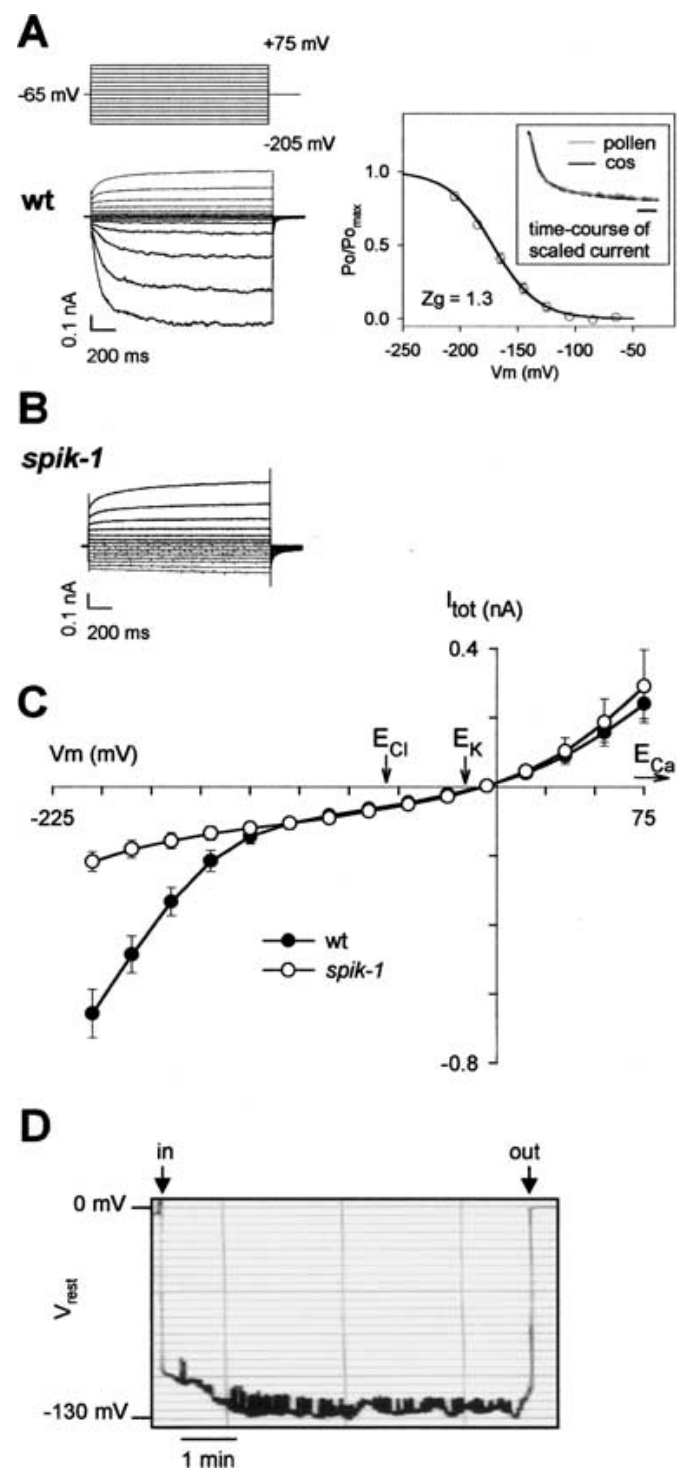

Figure 3. Electrical properties of the wild-type and spik-1 pollen membrane. $(A-C)$ Patch-clamp measurements on pollen grain protoplasts. External and internal $\mathrm{K}^{+}$concentrations were $50 \mathrm{mM}$ and $100 \mathrm{mM}$, respectively. (A) Pollen from wild-type (wt) plants. (Left panel) Voltage-clamp protocol and typical example of currents recorded in whole protoplasts. (Right panel) Activation properties of the time-dependent inwardly rectifying conductance. The solid line is a Boltzmann fit of the mean $( \pm \mathrm{SE}$; $n=6)$ relative open probability $\left(\mathrm{Po} / \mathrm{Po}_{\max }\right)$ versus the membrane potential. ( $\mathrm{Zg})$ Equivalent gating charge obtained from the Boltzmann fit. The half-activation potential (from Boltzmann fit) is $-172 \mathrm{mV}$. (Inset) Comparison of activation kinetics of inwardly rectifying current in pollen protoplasts and in SPIK-expressing COS cells. Current traces obtained at $-205 \mathrm{mV}$ in $50 \mathrm{mM}$ external $\mathrm{K}^{+}$were scaled for easier comparison. Bar: $100 \mathrm{msec}$ (B) Typical example of currents recorded in pollen protoplasts from homozygous spik-1 plants. Same protocol as in $A$. (C) Current/ voltage relationship obtained with pollen protoplasts of both genotypes (mean $\pm \mathrm{SE} ; n=12$ for wt and 9 for spik-1). Arrows point to equilibrium potentials for $\mathrm{Cl}^{-}, \mathrm{K}^{+}$, and $\mathrm{Ca}^{2+}$ ions $\left(\mathrm{E}_{\mathrm{Cl}}\right.$, $\mathrm{E}_{\mathrm{K}}$, and $\left.\mathrm{E}_{\mathrm{Ca}}\right) .(D)$ Recording of resting membrane potential $\left(V_{\text {rest }}\right)$ in a young growing pollen tube. External $\left[\mathrm{K}^{+}\right]$was $1 \mathrm{mM}$. Arrows, (in) start or (out) end of cell impalement. 
over 5-10 min generally showed a quite stable hyperpolarized level with values in the $-120-\mathrm{mV}$ to $-134-\mathrm{mV}$ range (mean, $-127 \pm 2 \mathrm{mV}, n=7$ ) interspersed with short depolarized (10-20 mV) events (Fig. 3D). Comparison of these values of resting membrane potential with the activation threshold of the slowly activating, inwardly rectifying current recorded in pollen protoplasts $(\sim-100 \mathrm{mV}$; Fig. 3A; Fan et al. 2001) indicates that SPIK was open and at work in these conditions.

\section{The spik-1 mutation strongly affects in vitro pollen} germination and tube development

We used the fact that pollen can germinate and grow a tube in vitro to investigate the effects of the spik-1 mutation on pollen fitness, although in vitro growth does not completely mimic in vivo growth in terms of growth rate or tube length (Taylor and Hepler 1997). Differences in pollen germination and tube growth could be observed from one set of experiments to the other, both with wildtype and spik-1 pollen. Thus, the effect of the spik-1 mutation was studied using wild-type and spik-1 homozygous plants grown in parallel under the same conditions, the wild-type and spik-1 pollen grains being systematically germinated in parallel on the same slides. The concentration of $\mathrm{K}^{+}$in the germination medium was $100 \mu \mathrm{M}$ or $1 \mathrm{mM}$. The concentration of $\mathrm{K}^{+}$in the apoplast of the style tissues surrounding the growing pollen tube is unknown. However, the $100 \mu \mathrm{M}-1 \mathrm{mM}$ concentration range can be considered as physiologically relevant.

Six hours after having been deposited on $100 \mu \mathrm{M} \mathrm{K}^{+}$ coated slides, wild-type pollen grains (Fig. 4A) displayed longer tubes than spik-1 grains (Fig. 4B). For both pollen genotypes, detailed examination allowed to distinguish nongerminated grains (no tube) and, among those having grown a tube (germinated), two distinct populations. The first one displayed tubes shorter than $30 \mu \mathrm{m}$ after $6 \mathrm{~h}$ of incubation (as shown in Fig. 4C for spik-1 pollen) that did not grow further even after $2 \mathrm{~d}$. The second population displayed long tubes, here below called developed tubes, several hundred micrometers long $6 \mathrm{~h}$ after pollen deposition. As a consequence, two distinct length ranges were considered in the histogram analysis of tube length in wild-type or spik-1 pollen grains (Fig. 4D,E). Only the so-called developed tubes were considered for the Gaussian analysis of mean tube length (lines in Fig. 4D,E), which yielded $581 \pm 8 \mu \mathrm{m}$ and $340 \pm 13 \mu \mathrm{m}$ (mean $\pm \mathrm{SE}$ ), respectively, for wild-type and spik-1 pollen grains grown in $0.1 \mathrm{mM} \mathrm{K} \mathrm{K}^{+}$medium, the difference being significant $\left(t\right.$-test, $\left.P<10^{-10}\right)$. In all subsequent experiments, irrespective of mean values, the mean length of spik-1 developed tubes was $40 \%$ shorter than that of wild-type ones (see, e.g., Fig. 5C), the difference being always significant $\left(P<10^{-10}\right)$.

It is worth noting that in these experiments the mean wild-type tube length, obtained after a 6-h germination, was $\sim 5$ times greater than that recently reported (120 $\mu \mathrm{m})$ for Arabidopsis pollen after a 6-h germination in 0.1 $\mathrm{mM} \mathrm{K}{ }^{+}$and otherwise different experimental conditions
A wt pollen

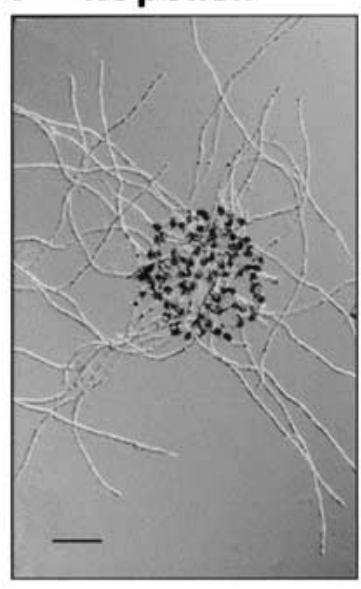

D

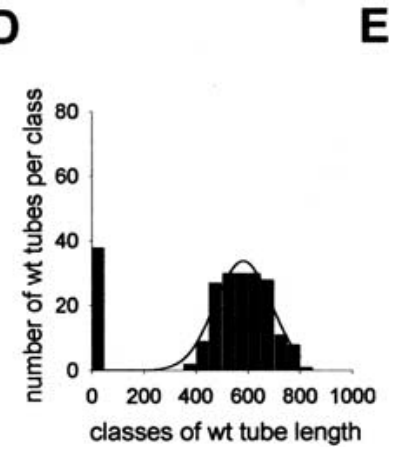

E
B spik-1 pollen
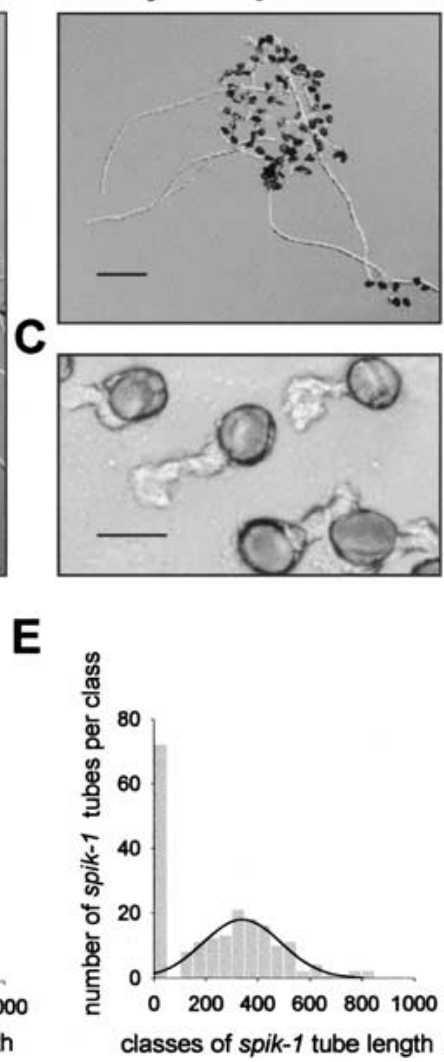

Figure 4. In vitro development of wild-type and spik-1 pollen. (A) Wild-type (wt) or $(B)$ spik-1 pollen germinated on $0.1 \mathrm{mM} \mathrm{K}^{+}$ medium (bar, $100 \mu \mathrm{m}) .(C)$ Non-developed (see text) spik-1 pollen tubes (bar, $15 \mu \mathrm{m})$. $(D, E)$ Histograms showing the length distribution of $(D)$ wild-type $(n=214)$ and $(E)$ spik-1 $(n=202)$ germinated grains on the $0.1 \mathrm{mM} \mathrm{K}^{+}$medium. The two histograms were fitted according to a Gaussian distribution (lines).

(Fan et al. 2001). In vivo fertilization occurs $\sim 2-3 \mathrm{~h}$ after pollination in Arabidopsis (Mansfield and Briarty 1991). The mean distance from stigmatic papillae to ovules being $\sim 1000 \mu \mathrm{m}$, this suggests a $300-$ to $500-\mu \mathrm{m} / \mathrm{h}$ tube growth rate in vivo. The germination protocol we used, which clearly favors tube growth when compared with the one used by Fan et al. (2001), is therefore likely to more closely mimic in vivo conditions.

Quantitative analyses of pollen fate (percentage of germinated grains and developed tubes as defined above) are shown for wild-type and spik-1 pollen grains in 0.1 and 1 $\mathrm{mM} \mathrm{K}{ }^{+}$media, respectively, in Figure 5, A and B. Of wild-type pollen grains, $\sim 70 \%-75 \%$ germinated; their germination rate was barely affected by modifying external $\mathrm{K}^{+}$from $0.1 \mathrm{mM}$ to $1 \mathrm{mM}$ (Fig. 5A). The spik-1 mutation poorly affected the overall germination rate, which was $60 \%-65 \%$, rather independent of the external concentration of $\mathrm{K}^{+}(0.1 \mathrm{mM}$ or $1 \mathrm{mM}$; Fig. $5 \mathrm{~B})$. On the other hand, the mutation resulted in a strong decrease (by $\sim 3$ times in $0.1 \mathrm{mM} \mathrm{K}^{+}$and $\sim 2$ times in $1 \mathrm{mM} \mathrm{K}^{+}$) in the percentage of developed tubes: the percentage of developed tubes was in the $45 \%-50 \%$ and $15 \%-25 \%$ range, 


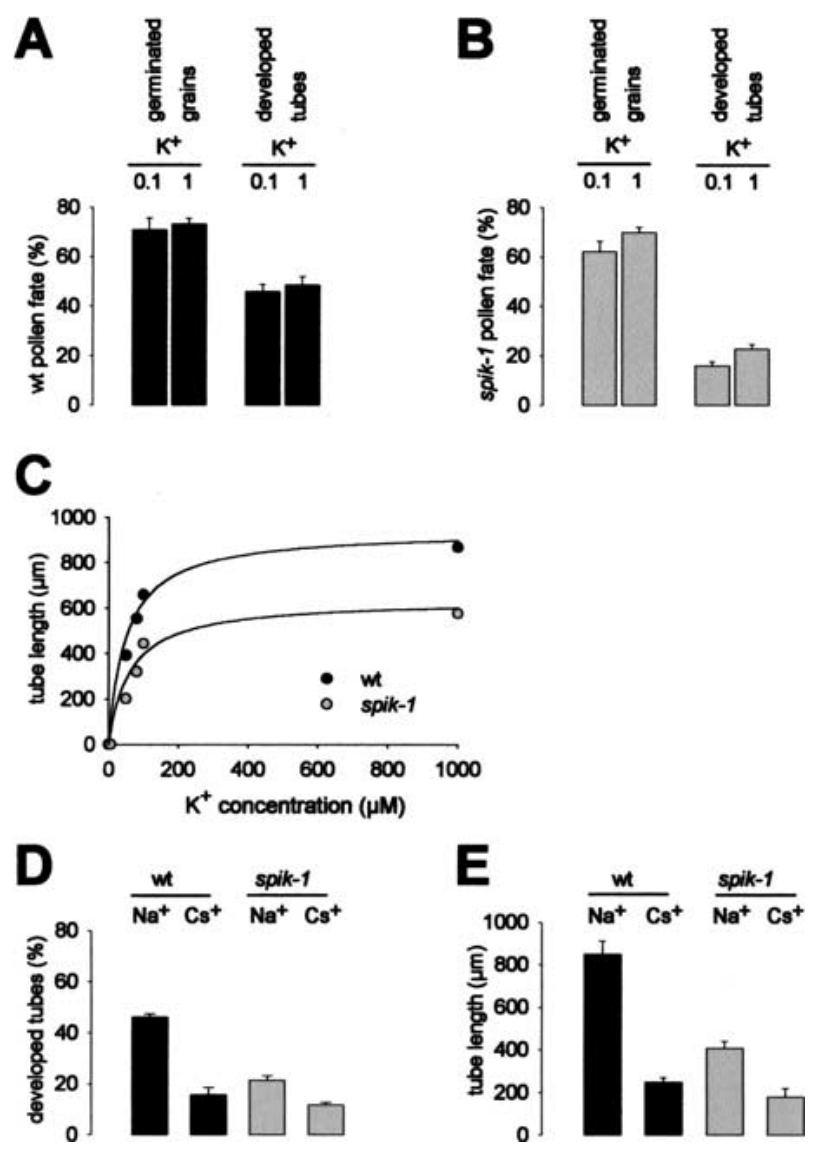

Figure 5. Quantitative analysis of wild-type and spik-1 pollen fate in vitro. $(A, B)$ Quantification of germinated grains and developed tubes in $(A)$ wild-type $(\mathrm{wt})$ and $(B)$ spik-1 pollen populations. The germination medium contained either 0.1 or $1 \mathrm{mM}$ $\mathrm{K}^{+}$. Means $\pm \mathrm{SE}$ of three independent experiments, each one including three replicates (at least 200 pollen grains per replicate). The differences between the percentages of developed tubes in the wild-type and the spik-1 populations are significant $\left(P<10^{-5}\right.$, $t$-test $)$ in both media. $(C)$ Effect of external $\mathrm{K}^{+}$concentration on wild-type (wt) and spik-1 pollen tube length. $\mathrm{K}^{+}$concentrations below $100 \mu \mathrm{M}$ were obtained by supplementing the $100 \mu \mathrm{M}$ germination medium with the $\mathrm{K}^{+}$chelator tetraphenylborate (TPB). Addition of $20 \mu \mathrm{M}, 50 \mu \mathrm{M}$, and $100 \mu \mathrm{M}$ TPB was calculated to reduce the free $\mathrm{K}^{+}$concentrations to $80 \mu \mathrm{M}, 50 \mu \mathrm{M}$, and $5 \mu \mathrm{M}$ (lowest concentration shown in the graph), respectively (see Materials and Methods). Mean \pm SE for at least 300 tubes (SE bars smaller than the symbol size). Lines show hyperbolic fits to the data (least squares fits): apparent $\mathrm{K}_{\mathrm{M}}$ of 50 and 61 $\mathrm{mM}$ for wild-type and spik-1 pollen grains, respectively. $(D, E)$ Effect of $\mathrm{Cs}^{+}$on percentage of developed tubes $(D)$ and tube length (E) for wild-type (black bars) or spik-1 (gray bars) pollen grains. Either $2 \mathrm{mM} \mathrm{NaCl}$ (control treatment) or $2 \mathrm{mM} \mathrm{CsCl}$ was added to $1 \mathrm{mM} \mathrm{K}^{+}$germination medium. Mean $\pm \mathrm{SE}$ for at least 800 pollen grains $(D)$ and 50 pollen tubes $(E)$ in both treatments. The depressive effect of $\mathrm{Cs}^{+}$is significant $\left(P<10^{-3}\right)$ in each genotype.

respectively, for wild-type and spik-1 grains (Fig. 5A,B). The effect of $\mathrm{K}^{+}$concentration on the mean tube length was investigated in the $5 \mu \mathrm{M}$ to $1 \mathrm{mM}$ range (see Materials and Methods). In both wild-type and spik-1 pollen, decreasing $\mathrm{K}^{+}$availability in the germination medium below $0.1 \mathrm{mM}$ was found to strongly affect the mean tube length, that is, the lower the $\mathrm{K}^{+}$concentration the shorter the tubes (Fig. 5C), with a total lack of development in the presence of $\sim 5 \mu \mathrm{M}$ free $\mathrm{K}^{+}$. In the $50 \mu \mathrm{M}$ to $1 \mathrm{mM}$ concentration range, the spik-1 mutation reduced the tube length by an average factor of $40 \%-50 \%$.

$\mathrm{Cs}^{+}$is known to selectively block inward $\mathrm{K}^{+}$currents through plant $\mathrm{K}^{+}$-selective inwardly rectifying Shaker channels while leaving outward $\mathrm{K}^{+}$currents and poorly selective cation channels unaffected (Fig. 2D; White 1997). Adding $2 \mathrm{mM} \mathrm{Cs}^{+}(\mathrm{CsCl})$ to the $1 \mathrm{mM} \mathrm{K}^{+}$germination medium reduced both the percentage of developed tubes (Fig. 5D) and the average tube length (Fig. 5E). As expected, the effects of this treatment were less pronounced on spik-1 pollen than on wild-type pollen.

\section{The spik-1 mutation results in impaired pollen competitive ability}

The impairment of pollen development observed in vitro suggested that, in planta, the spik-1 mutation could result in decreased pollen fitness and competitive ability. Such a decrease would be liable to produce a distorted transmission rate of the spik-1 and wild-type alleles in the progeny of heterozygous (SPIK/spik-1) plants. To analyze this, we took advantage of the fact that the disrupting T-DNA carries a copy of the nptII gene, which confers resistance to kanamycin. Thus, $F_{1}$ plants free from the transforming T-DNA (i.e., homozygous wildtype plants) could be identified as sensitive to the antibiotic (white plantlets with reduced growth). Arabidopsis undergoes efficient self-fertilization with negligible outcrossing even under closely spaced laboratory growth conditions (Snape and Lawrence 1971; Abbott and Games 1989); strict self-fertilization was therefore assumed. In the $F_{1}$ progeny of so-called control plants, hemizygous for the nptII transgene, the mean percentage of homozygous wild-type plants /sensitive to kanamycin) was found to be close to $25 \%$, as expected for the Mendelian segregation of a single recessive trait (Fig. 6A, white bars). In the $\mathrm{F}_{1}$ progeny of heterozygous (SPIK) spik-1) plants the mean percentage of homozygous wildtype plants was found to be close to $31 \%$. The spik-1 mutation therefore resulted in a significant decrease in pollen competitive ability. From the frequency of $31 \%$, assuming that the spik-1 mutation does not affect the ability of the ovules to be fertilized and to develop into seeds, the probability of fertilization by wild-type pollen $(\mathrm{Pwt})$ in competition with spik-1 pollen grain can be estimated to be 0.62 (i.e., $0.31 \times 2$ ). Given this, the probability of fertilization by a spik-1 pollen grain $\left(\mathrm{P}_{\text {spik-1 }}\right)$ is 0.38 (i.e., 1 - 0.62).

The decrease in spik-1 pollen competitive ability was further confirmed by analyzing the percentage of homozygous wild-type plants in three successive generations obtained by bulk amplification, starting from either SPIK/spik-1 heterozygous plants or from control plants hemizygous for the $n p t I I$ transgene (Fig. 6B). A persistent distortion in allele segregation was observed from $F_{1}$ to 
A
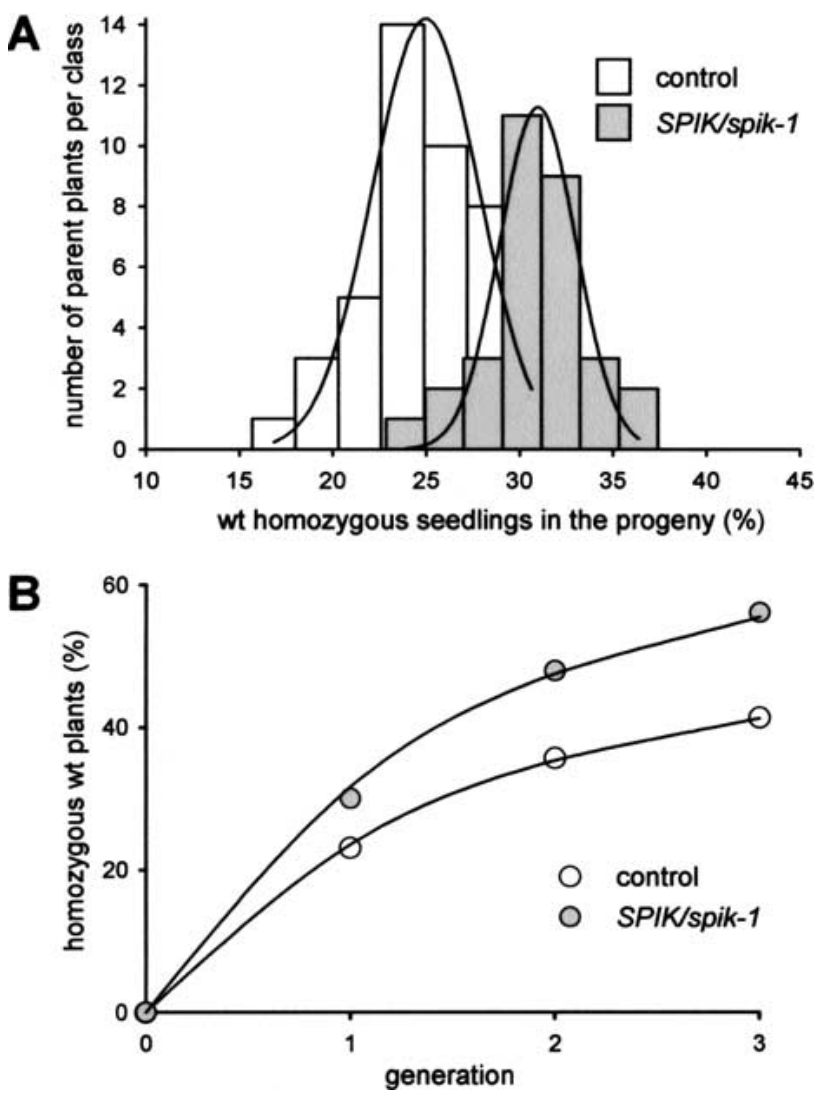

Figure 6. SPIK gene disruption results in reduced pollen fitness. (A) Histogram analysis of kanamycin-sensitive seedling percentage in the progeny of 31 SPIK/spik-1 plants (gray bars) and 44 control plants (white bars). The disrupting T-DNA (Fig. 1A) contains a gene (nptII) conferring resistance to kanamycin. Sowing seeds from plants self-fertilized heterozygous (SPIK) spik-1) or hemizygous for the transgene nptII (control) on kanamycin medium $(50 \mu \mathrm{g} / \mathrm{mL})$ allowed the census (in percent) of homozygous wild-type seedlings $(\mathrm{wt}$, free from disrupting $\mathrm{T}$ DNA and thus kanamycin-sensitive) in the progeny of each plant. At least 300 seedlings were tested for each parental plant. Percentage data were sorted into eight classes for each parental genotype. The data (number of parent plants belonging to each class) were fitted by a Gaussian distribution. (B) Evolution of the census of wild-type homozygous genotype through three subsequent self-fertilizing generations issued from SPIK/spik-1 plants (gray symbols) or from control plants (white symbols). Thirtyfive plants $\left(\mathrm{F}_{0}\right)$ of each genotype were grown. Their seeds $\left(\mathrm{F}_{1}\right)$ were harvested in bulk, of which at least 1200 seeds were sown on kanamycin medium (homozygous wt genotype census) and at least 100 seeds were sown on compost and grown in the greenhouse for producing the subsequent $\left(\mathrm{F}_{2}\right)$ generation. The same protocol was applied to analyze the $\mathrm{F}_{2}$ seeds, and to produce and analyze the $\mathrm{F}_{3}$ generation. It was assumed that pure self-fertilization occurred and that the spik-1 mutation affected only pollen competitive ability. Within this framework, the predicted percentage of homozygous wild-type genotype in generation $n$ is $\% \mathrm{wt}_{n}=100 \mathrm{Pwt} \times \mathrm{S}_{\mathrm{n}}$, where

$$
\mathrm{S}_{\mathrm{n}}=\sum_{i=1}^{n} 1 / 2^{i},
$$

and Pwt is the probability of fertilization by wild-type pollen in competition with spik-1 pollen. The value of the unknown parameter Pwt was adjusted to fit the data using a MarquardtLevenberg algorithm (least-squares fitting). This yielded $\mathrm{Pwt}=0.47$ for the control genotype and $\mathrm{Pwt}=0.64$ for the SPIK/ spik-1 genotype.
$\mathrm{F}_{3}$ in the progeny of the SPIK/spik-1 heterozygous plants. Over the three generations, the probability of fertilization by wild-type pollen in competition with spik-1 pollen was estimated to be 0.63 , and therefore the probability of fertilization by spik-1 pollen to be 0.37 (i.e., $1-0.63)$.

In vitro tests (Figs. 4,5) revealed that wild-type pollen grains displayed both a two-to-three-times higher tube development score and a 1.7-times longer tube length than spik-1 pollen grains. Therefore, assuming a cumulative effect of these advantages, a $\mathrm{Pwt} / \mathrm{P}_{\text {spik-1 }}$ ratio of 3.4 to 5.1 would be predicted from these in vitro tests, which is much higher than the 1.7 ratio $(0.63 / 0.37)$ deduced from in vivo tests (Fig. 6B). This indicates that the spik-1 mutation has more drastic effects on pollen tube development in vitro than in vivo, in agreement with the contention that in vitro media fall short of mimicking the in vivo conditions (Lord 2000).

\section{Discussion}

The SPIK Shaker channel mediates inward $\mathrm{K}^{+}$current in the pollen plasma membrane

SPIK is the first ion channel active in the pollen membrane to be identified at the molecular level. This channel has been cloned in the model species Arabidopsis thaliana. Based on sequence analysis, the two closest relatives of SPIK within the Arabidopsis Shaker family are AKT6 (Lacombe et al. 2000; in BAC F8B4, GenBank accession no. AL034567; 76\% identity with SPIK), also called AKT5 (Mäser et al. 2001), and AKT1 (Sentenac et al. 1992; 55\% identity with SPIK). The AKT6 channel (Lacombe et al. 2000) has not yet been characterized at the functional level. AKT1 has been characterized both in planta (Hirsch et al. 1998) and in heterologous contexts (Gaymard et al. 1996; Bertl et al. 1997) as an inwardly rectifying $\mathrm{K}^{+}(\mathrm{Kin})$ channel. When expressed in COS cells, SPIK also behaves as a Kin channel. Its single channel conductance is in the range of that of other Shaker channels characterized in Arabidopsis. Like the other Arabidopsis Shaker channels characterized so far, SPIK is highly selective for $\mathrm{K}^{+}$. It activates independently of the external $\mathrm{K}^{+}$concentration, as also shown for the AKT1 (Gaymard et al. 1996) and KAT1 (Véry et al. 1995) Kin channels from Arabidopsis.

The strong sensitivity of SPIK to external pH (Fig. 2B) could allow regulation of $\mathrm{K}^{+}$influx by the apoplastic $\mathrm{pH}$, itself under the control of $\mathrm{H}^{+}$transport activity of the germinating pollen grain and/or of the neighboring cells. The hypothesis that the sensitivity of Shaker channels to $\mathrm{pH}$ could play a role in coupling $\mathrm{K}^{+}$and $\mathrm{H}^{+}$fluxes has been also proposed for the guard cell Kin channels KAT1 from Arabidopsis and KST1 from potato (Müller-Röber et al. 1995; Hoth et al. 1997; Hoth and Hedrich 1999).

Comparison of Kin currents recorded in Arabidopsis pollen protoplasts (this study; Fan et al. 2001) with the functional properties of SPIK analyzed in COS cells reveals similarity in the following features: current activation kinetics, apparent gating charge, sensitivity to ex- 
ternal $\mathrm{pH}$, and absence of sensitivity to external $\mathrm{Ca}^{2+}$ in the $1 \mathrm{mM}-10 \mathrm{mM}$ range. The slight difference in activation threshold of $\sim-100 \mathrm{mV}$ in pollen protoplasts (Fig. $3 \mathrm{~A}$; Fan et al. 2001) versus $-125 \mathrm{mV}$ in COS cells (Fig. 2B) can be ascribed to the fact that the activation threshold of Shaker channels expressed in heterologous systems is known to be sensitive to the host context, varying from one expression system to the other (Dreyer et al. 1999|, and also to the expression level within the same expression system (Véry et al. 1994). It is also worth noting that, at the single-channel level, the only Kin channel so far described in pollen plasma membrane has a unitary conductance (in Lily) of 19 pS in $100 \mathrm{mM}$ external K+ (Obermeyer and Kolb 1993; Fig. 4), very close to that of SPIK (14 pS in $\left.50 \mathrm{mM} \mathrm{K}^{+}\right)$. Finally, comparison of the electrophysiological recordings obtained in wildtype and spik-1 pollen-grain protoplasts indicates that the spik-1 mutation prevents expression of any slowly activating Kin channel in the cell membrane. Therefore, the simplest hypothesis is that SPIK is the main channel endowed with these functional features active on the pollen membrane, and that the spik-1 mutation prevents expression of functional SPIK channels. This hypothesis is further supported by RT-PCR analyses suggesting that, within the Shaker channel gene family, the inward channel displaying the highest expression level in pollen is SPIK (Fig. 1F,G). Alternatively, if other Shaker Kinchannel subunits were expressed in pollen at significant levels (e.g., AKT2, KAT1, or KAT2; see Fig. 1G), allowing formation of heterotetrameric channels endowed with functional properties similar to those of SPIK (in COS cells), the hypothesis would be that spik-1 behaves as a dominant-negative mutation. Whatever the mechanisms involved, it is clear that functional expression of SPIK is required for the pollen membrane to display significant Kin channel activity, and that the spik-1 mutation knocks out this activity.

\section{Role of SPIK in pollen}

The depressive effect of decreased $\mathrm{K}^{+}$availability on pollen tube development, resulting in a total absence of tube growth when the free concentration of $\mathrm{K}^{+}$is decreased to $\sim 5 \mu \mathrm{M}$, indicates that a minimal concentration of $\mathrm{K}^{+}$is absolutely required for sustained growth, in agreement with previous observations (Weisenseel and Jaffe 1976). $\mathrm{K}^{+}$influx in the growing tube is necessary for maintenance of the cytosolic $\mathrm{K}^{+}$concentration despite the increase in cell volume. It is also widely accepted (although not directly shown) that the pollen tube uses $\mathrm{K}^{+}$(Weisenseel and Jaffe 1976; Weisenseel and Wenisch 1980; Messerli et al. 1999), together with other osmoticums such as sucrose (Stadler et al. 1999), to control its turgor. A minimal cell turgor is, indeed, necessary for rapid tube growth, although turgor alone is not sufficient to explain the variation in tube growth rates seen in vitro (Benkert et al. 1997).

The spik-1 mutation strongly affects the capacity of the pollen to develop a tube in vitro, in the presence of physiologically relevant $\mathrm{K}^{+}$concentrations. The depressive effect of the Kin-channel blocker $\mathrm{Cs}^{+}$(mimicking the effects of the spik-1 mutation) further confirms that Kin-channel activity mediating $\mathrm{K}^{+}$uptake is required for pollen tube development. It can be calculated that a continuous $\mathrm{K}^{+}$current of $\sim-10 \mathrm{pA}$ is required for maintaining an internal $\mathrm{K}^{+}$concentration of $\sim 120 \mathrm{mM}$ (Weisenseel and Jaffe 1976; Bashe and Mascarenhas 1984) in a tube of $5-\mu \mathrm{m}$ diameter growing at $2.5 \mu \mathrm{m} / \mathrm{min}$. Could SPIK activity significantly contribute to this current? In young Arabidopsis pollen tubes in $1 \mathrm{mM}$ external $\mathrm{K}^{+}$, we recorded resting-membrane potential values $(-127 \pm 2$ $\mathrm{mV}$ ) quite similar to those reported in germinated lily pollen grains in the presence of $1 \mathrm{mM} \mathrm{K}^{+}$(Weisenseel and Jaffe 1976). They are more negative than the activation potential of SPIK $(-100 \mathrm{mV}$ in Fig. 3A), and slightly more negative than the $\mathrm{K}^{+}$equilibrium potential $\left(\mathrm{E}_{\mathrm{K}}\right.$, expected to be close to $-120 \mathrm{mV}$; Weisenseel and Jaffe 1976; Bashe and Mascarenhas 1984). In these conditions (1 mM external $\mathrm{K}^{+}$and membrane potential of $-127 \mathrm{mV}$ ), from the current-voltage curves obtained in pollen protoplasts (Fig. 3C) and the curve describing the effect of external $\mathrm{K}^{+}$concentration on SPIK current (Fig. 2C; $\mathrm{K}_{\mathrm{M}}$ of 14 $\mathrm{mM})$, it can be estimated that the slowly activating Kin current (dependent on SPIK expression) entering the pollen grain is close to $-4 \mathrm{pA}$. This value is likely to underestimate the SPIK contribution to $\mathrm{K}^{+}$influx into the germinating pollen because measured membrane potentials are likely to have been underestimated. This is widely assumed when membrane potentials are determined by intracellular microelectrodes, as "even in the case of high-quality impalement a significant portion of the membrane potential would be dissipated at the impalement site" (Gassmann and Schroeder 1994). For instance, assuming that the actual membrane potential was $\sim 20 \mathrm{mV}$ more negative than the measured values, the SPIK current entering the pollen grain would be close to $-9 \mathrm{pA}$. Therefore, our data support a model in which SPIK-dependent $\mathrm{K}^{+}$-channel activity would significantly contribute to wholesale $\mathrm{K}^{+}$influx, allowing control of internal $\mathrm{K}^{+}$concentration for sustained tube growth.

No estimate of the membrane potential of the growing pollen tube is available in planta. Also, the concentration of $\mathrm{K}^{+}$in the apoplast of the cells surrounding the growing pollen tube is unknown. However, the fact that the spik-1 mutation affects in vitro pollen tube development even when the concentration of $\mathrm{K}^{+}$in the external solution is as low as $50 \mu \mathrm{M}$ (Fig. $5 \mathrm{C}$ ) suggests that SPIKchannel activity could allow high-affinity $\mathrm{K}^{+}$uptake, sustained by very negative membrane potentials. It is worthwhile noting that a similar situation has been described for the Arabidopsis AKT1 $\mathrm{K}^{+}$channel expressed in root hairs and cortical cells (Hirsch et al. 1998). The possible involvement under low external $\mathrm{K}^{+}$conditions of Kin channels in wholesale $\mathrm{K}^{+}$uptake during pollen tube germination has, however, been questioned (Messerli et al. 1999), highly negative resting membrane potentials having rarely been reported (Weisenseel and Wenisch 1980; Obermeyer and Blatt 1995; Messerli et al. 1999). Active $\mathrm{K}^{+}: \mathrm{H}^{+}$symport activity has therefore been 
assumed to be required for efficient $\mathrm{K}^{+}$uptake, especially at high growth rate (Messerli et al. 1999, 2000).

In planta, the spik-1 mutation strongly affects pollen competitive ability, the probability of fertilization by the mutant pollen being $\sim 1.6-1.7$ times lower than that by the wild-type one. In the absence of SPIK-type channel activity, pollen tube development in planta (and in vitro, in $\sim 20 \%$ of the cells; Figs. $4 \mathrm{~B}, 5 \mathrm{~B}$ ) could be owing to transport systems responsible for the background inward $\mathrm{K}^{+}$ current observed in spik-1 (and wild-type) pollen (Fig. 3B,C).

\section{Conclusion}

Pollen tube growth has been extensively studied, in particular because it provides an attractive model for investigating cell polarity and morphogenesis in tip growing cells (Derksen 1996; Taylor and Hepler 1997; Feijó et al. 2001). The molecular mechanisms underlying rapid and polarized growth in these cells are still poorly understood. The demonstration that the spik-1 mutation affects pollen tube growth, and thereby pollen fitness, is therefore a highly significant result. Regarding the effect on pollen fitness, it has been emphasized that alleles that are measurably lowered in frequency in a few generations have, at the population level, essentially the same fate as a lethal mutation (Gilliland et al. 1998). The fact that, in the progeny of SPIK/spik-1 plants, the wild-type genotype rapidly and significantly takes the advantage over the mutant genotype indicates that SPIK is essential, and is under a high selection pressure.

\section{Materials and methods}

\section{SPIK cDNA cloning}

A sequence encoding a $\mathrm{K}^{+}$channel of the plant Shaker family (Zimmermann and Sentenac 1999) was identified in the F3N11 BAC (GenBank accession no. AC006053). A PCR fragment was amplified from this BAC and used as a probe for Northern blot experiments. Expression having been localized in flowers (Fig. 1), flower poly $(\mathrm{A})^{+} \mathrm{RNAs}$ were isolated and used for cDNA isolation by $5^{\prime}$ and $3^{\prime}$ RACE-PCR. Six cDNAs were obtained, sharing the same 2667-bp ORF. This SPIK ORF was amplified with Pfu polymerase (Promega) by reverse transcription-PCR on flower poly $(\mathrm{A})^{+}$RNAs with primers containing an NheI site upstream of the ATG codon (5'-GCTAGCATGGAGAAGAA GAAGGTATGGTTTTGGGG-3') and an NotI site downstream of the Stop codon (5'-GCGGCCGCTCAAGGATCCCTTGATAGAAGGAGAAAATCGCCATCTC-3'). The amplified fragment was cloned into the pCI expression vector (Promega) for heterologous expression in COS cells.

\section{RT-PCR experiments}

About 800 inflorescences from Arabidopsis thaliana plants grown in the greenhouse were split into four vials filled with 30 $\mathrm{mL}$ of the basal germination medium (see below). After vigorous shaking (vortex) to allow the release of pollen grains, the medium was filtered through one layer of Miracloth (CalBiochem) and centrifuged ( $4000 \mathrm{~g}$ for $5 \mathrm{~min})$, allowing recovery of a pure pollen-grain preparation (checked under the microscope). The pellet was resuspended in $200 \mu \mathrm{L}$ of RNA extraction buffer (Lobréaux and Briat 1992) and ground in a mortar, and the total RNA was purified according to Lobréaux and Briat (1992). The final pellet was resuspended in $20 \mu \mathrm{L}$ of $\mathrm{H}_{2} \mathrm{O}$, and $5 \mu \mathrm{L}$ was used for first-strand synthesis by MMLV reverse transcriptase (Promega) with 10 pmole of oligo(dT)20 (final volume $20 \mu \mathrm{L}$ ). The reaction medium was diluted 10 -fold in water, and $5 \mu \mathrm{L}$ was used for each PCR reaction. For each Shaker gene, two independent couples of primers (sequences available upon request) surrounding introns were used for the PCR reaction (final volume $50 \mu \mathrm{L} ;$ ExtraPol I, Eurobio). Expression of the EF1 $\alpha$ gene (Axelos et al. 1989) was monitored as a control.

\section{Expression analysis using the GUS reporter gene}

The SPIK promoter region was isolated by PCR on the BAC F3N11 DNA with a direct primer containing a BamHI site $\left(5^{\prime}\right.$ GGATCCGTGTAACGAGAATAAAAGTGGTTTC-3') and a reverse primer introducing an NcoI site at the initiation ATG codon (5'-CCATGGTTCAGATCCCTCTCTCTTTCTTTTT CC-3'). The amplified fragment $(\sim 2.5 \mathrm{~kb})$ was translationally fused to the GUS coding sequence in pBI320.X (this plasmid carries a unique $\mathrm{NcoI}$ site at the first initiation codon of the promoterless GUS-3' nopaline synthase reporter gene). This construct was introduced into the SacI site of the pMOG 402 binary vector. The resulting plasmid was introduced into Agrobacterium tumefaciens MP90 (Höfgen and Willmitzer 1988). Arabidopsis thaliana was transformed with agrobacteria using the infiltration method (Bechtold et al. 1993). GUS histochemical staining was performed as previously described (Lagarde et al. 1996).

\section{Isolation of a T-DNA-tagged plant disrupted in the SPIK gene}

The spik-1 mutant was obtained by PCR screening of a collection of $\sim 40,000$ Arabidopsis T-DNA insertion mutants (Wassilevskija ecotype; library constructed by the Laboratoire de Génétique et Amélioration des Plantes, INRA Versailles, France) with primers corresponding to the SPIK gene and to the T-DNA left and right borders. The exact position of the T-DNA insertion was determined by sequencing the T-DNA flanking sequences. Plants homozygous for the disruption and hemizygous plants were selected (by PCR) in the progeny of the positive line.

\section{Expression and characterization of SPIK in COS cells}

COS-7 cells were cotransfected with 33 ng of the transfection marker pIRES-CD8 plasmid and $2 \mu \mathrm{g}$ of pCI-SPIK per dish as described (Reyes et al. 1998). Patch-clamp experiments were carried out 2-3 d after transfection. Transfected cells were identified by anti-CD8 antibody-coated beads (Dynabeads M450, Dynal ASA). Classical patch-clamp methods (Hamill et al. 1981) were applied, using an Axopatch 200A amplifier (Axon Instruments Inc.). Data were sampled $(2 \mathrm{kHz}$, filtering $1 \mathrm{kHz})$ and analyzed with pClamp6 (Axon Instruments) or WinASCD (G. Droogmans, University of Leuwen, Belgium) softwares. Voltage drops through series resistance were corrected (75\%) during acquisition using the built-in compensation feature of the amplifier. Leak current was digitally subtracted before quantitative analyses of the data (current recordings shown in figures are raw data). At the end of cell-attached patch-clamp experiments, the cell resting potential was measured after rupture of the patch, by clamping the whole-cell current to zero. All patch-clamp solutions were adjusted to $300 \mathrm{mOsM}$ with mannitol. The ex- 
ternal basal solution (bath in whole-cell configuration and pipette filling in cell-attached configuration) contained $1 \mathrm{mM}$ $\mathrm{CaCl}_{2}, 3 \mathrm{mM} \mathrm{MgCl}$, $10 \mathrm{mM} \mathrm{Mes/Tris} \mathrm{(pH} 5.0$ or $\mathrm{pH} 6.0$ ), or 10 $\mathrm{mM}$ Hepes/Tris ( $\mathrm{pH}$ 7.4). Unless otherwise stated, the $\mathrm{pH}$ was 6.0 and the concentration of $\mathrm{K}^{+}$(added as $\mathrm{Cl}^{-}$salt) was $50 \mathrm{mM}$. When the concentration of $\mathrm{K}^{+}$was lower than $50 \mathrm{mM}$, the solution was supplemented with $\mathrm{NaCl}$ for ionic strength adjustment (sum of the $\mathrm{K}^{+}$and $\mathrm{Na}^{+}$concentrations set to $50 \mathrm{mM}$ ), assuming no significant block of SPIK by $\mathrm{Na}^{+}$as for several other plant Shakers (e.g., KAT1, Véry et al. 1995; AKT1, Gaymard et al. 1996; AKT2, Lacombe et al. 2000). For $\mathrm{Cs}^{+}$block experiments, the external concentration of $\mathrm{KCl}$ was $10 \mathrm{mM}$, and that of $\mathrm{CsCl}$ was 0 (control), $50 \mathrm{mM}$, or $90 \mathrm{mM}$ (supplemented with 90,40 , and $0 \mathrm{mM} \mathrm{NaCl}$, respectively). In experiments addressing SPIK ionic selectivity, currents measured in $50 \mathrm{mM}$ $\mathrm{KCl}$ were compared with those recorded in $50 \mathrm{mM} \mathrm{XCl}\left(\mathrm{X}^{+}\right.$ being $\mathrm{Na}^{+}, \mathrm{Li}^{+}, \mathrm{Rb}^{+}$, or $\mathrm{NH}_{4}{ }^{+}$). The internal medium (whole-cell experiments) was comprised of $150 \mathrm{mM} \mathrm{KCl}, 3 \mathrm{mM} \mathrm{MgCl}$, 5 mM MgATP, 5 mM EGTA, and 10 mM Hepes/NaOH (pH 7.2).

\section{Patch-clamp on pollen protoplasts}

Ten flower buds were collected and vortexed in $1 \mathrm{~mL}$ of a solution containing $1 \mathrm{mM} \mathrm{KNO}_{3}, 0.2 \mathrm{mM} \mathrm{KH}_{2} \mathrm{PO}_{4}, 1 \mathrm{mM} \mathrm{MgSO}$, $1 \mu \mathrm{M} \mathrm{KI}, 0.1 \mu \mathrm{M} \mathrm{CuSO}_{4}, 5 \mathrm{mM} \mathrm{CaCl}_{2}, 5 \mathrm{mM}$ Mes, $1.6 \mathrm{mM}$ Tris (pH 5.8), $1 \mathrm{M}$ sorbitol, and $0.5 \mathrm{M}$ glucose. Filtration on $100-\mu \mathrm{m}$ mesh resulted in recovery of a fairly pure pollen-grain preparation. After centrifugation $(10,000 \mathrm{~g}$ for $1 \mathrm{~min})$, the supernatant was discarded, and $0.5 \mathrm{~mL}$ of the digestion solution (same as above, complemented with $1 \%$ [w/w] cellulase [RS, Onozuka], $0.5 \%$ macerozyme [Onozuka], and $0.2 \%$ BSA) was added. Digestion occurred at $30^{\circ} \mathrm{C}$ for $1 \mathrm{~h}$ with gentle shaking. The suspension was then centrifuged for $5 \mathrm{~min}$ at $1000 \mathrm{~g}$, and the supernatant was replaced by $1 \mathrm{~mL}$ of patch-clamp bath solution containing $50 \mathrm{mM} \mathrm{K}$-glutamate, $10 \mathrm{mM} \mathrm{CaCl}_{2}, 5 \mathrm{mM} \mathrm{Mes} \mathrm{(pH} \mathrm{5.7),}$ and 1.35 $\mathrm{M}$ sorbitol (for osmolarity adjustment). Patch-clamp experiments were performed in the whole-cell configuration as described above for COS cells. The patch pipette solution was $100 \mathrm{mM}$ K-glutamate, $1 \mathrm{mM} \mathrm{MgCl}_{2}, 5 \mathrm{mM}$ EGTA, $2 \mathrm{mM}$ MgATP, $10 \mathrm{mM}$ HEPES, $20 \mathrm{mM}$ Tris (pH 7.2), and 1.25 M sorbitol.

\section{Resting-membrane potential measurements}

Pollen grains were allowed to germinate for $1-2 \mathrm{~h}$ on a slide coated with a gelosed germination medium containing $1 \mathrm{mM}$ $\mathrm{KCl}$ (see next section below). Then the slide was covered with liquid medium (2-mm height) of the same composition for resting-membrane potential measurements. Tubes continued to grow in these conditions for at least $0.5 \mathrm{~h}$. Impalement electrodes were pulled from soft glass capillaries (Micro hematocrit, Modulohm) with a one-step vertical puller (Narishige), and filled with $3 \mathrm{M} \mathrm{KCl}$. Their resistance was 10-20 M 2 . The electrometer was an Axoprobe-1A (Axon Instruments). Restingmembrane potentials of young pollen tubes $(50-150 \mu \mathrm{m})$ were recorded on a chart recorder.

\section{Pollen germination analysis}

Plants were grown in the greenhouse until flowering. The pollen was collected from freshly dehiscent anthers and dabbed on glass slides coated with a thin layer $(\sim 30 \mu \mathrm{m})$ of germination medium. Wild-type and spik-1 pollen grains were always germinated in parallel on the same slides. Slides were incubated at $25^{\circ}-28^{\circ} \mathrm{C}$ for $6 \mathrm{~h}$ and then photographed (under microscope), to determine germination rates and tube lengths (AnalySIS Pro 3 software, Soft Imaging System GmbH). The basal germination medium contained $1 \%$ low melting point agarose, $200 \mathrm{mM}$ sucrose, $1.6 \mathrm{mM}$ boric acid, and $3 \mathrm{mM}$ calcium nitrate at $\mathrm{pH} 6.0$ (Thorsness et al. 1993). Because of contaminating $\mathrm{K}^{+}$in agarose and sucrose, the nominal concentration of this cation in the medium was $\sim 80-90 \mu \mathrm{M}$. Addition of $\mathrm{KCl}$ ensured that the final concentration of $\mathrm{K}^{+}$in the medium was $100 \mu \mathrm{M}$ (controlled by flame spectroscopy assay). $\mathrm{KCl}$ or the $\mathrm{K}^{+}$chelator tetraphenylborate (TPB; Bellando 1989) was added in some experiments to increase or decrease the concentration of free $\mathrm{K}^{+}$in the germination medium. The dissociation constant of the TPB- $\mathrm{K}^{+}$complex was estimated to be $\sim 0.3 \mu \mathrm{M}$ by measuring the changes in $\mathrm{K}^{+}$activity in response to increased amounts of TPB with a $\mathrm{K}^{+}$-selective electrode, and assuming a first-order dissociation kinetics for the TPB- $\mathrm{K}^{+}$complex.

\section{Acknowledgments}

We are grateful to S.A. Johnson for advice on in vitro pollen germination; to W.-H. Wu for the protocol of Arabidopsis pollen protoplast preparation; to B. Dreyfus and J.-C. Cleyet-Marel for their kind welcome to their laboratory (LSTM, CIRAD Baillarguet, Montpellier, France) to do pollen tube growth analysis; and to P. Berthomieu, I.A. Lefevre. and S. Zimmermann for helpful discussions and comments on the manuscript.

The publication costs of this article were defrayed in part by payment of page charges. This article must therefore be hereby marked "advertisement" in accordance with 18 USC section 1734 solely to indicate this fact.

\section{References}

Abbott, R.J. and Games, M.F. 1989. Population genetic structure and outcrossing rate of Arabidopsis thaliana (L.) Heynh. Heredity 62: 411-418.

Ache, P., Becker, D., Ivashikina, N., Dietrich, P., Roelfsema, M.R.G., and Hedrich, R. 2000. GORK, a delayed outward rectifyer expressed in guard cells of Arabidopsis thaliana, is a $\mathrm{K}^{+}$-selective, $\mathrm{K}^{+}$-sensing ion channel. FEBS Lett. 486: 9398.

The Arabidopsis Genome Initiative. 2000. Analysis of the genome sequence of the flowering plant Arabidopsis thaliana. Nature 408: 796-815.

Axelos, M., Bardet, C., Liboz, T., Le Van Thai, A., Curie, C., and Lescure, B. 1989. The gene family encoding the Arabidopsis thaliana translation elongation factor EF-1 $\alpha$ : Molecular cloning, characterization and expression. Mol. Gen. Genet. 219: 106-112.

Bashe, D. and Mascarenhas, J.P. 1984. Changes in potassium ion concentrations during pollen dehydration and germination in relation to protein synthesis. Plant Sci. Lett. 35: 55-60.

Bechtold, N., Ellis, J., and Pelletier, G. 1993. In planta Agrobacterium mediated gene transfer by infiltration of adult Arabidopsis thaliana plants. C.R. Acad. Sci. Paris 316: 11941199.

Bellando, M. 1989. The alkaline tetraphenylborates as chemiostatic agents for maintaining a low and controlled $\mathrm{K}^{+}$-activity in the high-affinity $\mathrm{K}^{+}$uptake process. In Plant membrane transport: The current position (eds. J. Dainty et al.), pp. 75-76. Elsevier Science, Amsterdam.

Benkert, R., Obermeyer, G., and Bentrup, F.-W. 1997. The turgor pressure of growing Lily pollen tubes. Protoplasma 198: 1-8.

Bertl, A., Reid, J.D., Sentenac, H., and Slayman, C.L. 1997. Functional comparison of plant inward-rectifier channels ex- 
pressed in yeast. J. Exp. Bot. 48: 405-413.

Bouchez, D., Camilleri, C., and Caboche, M. 1993. A binary vector based on Basta resistance for in planta transformation of Arabidopsis thaliana. C.R. Acad. Sci. Paris 316: 11881193.

Cabrillac, D., Cock, J.M., Dumas, C., and Gaude, T. 2001. The S-locus receptor kinase is inhibited by thioredoxins and activated by pollen coat proteins. Nature 410: 220-223.

Cao, Y., Ward, J.M., Kelly, W.B., Ichida, A.M., Gaber, R.F., Anderson, J.A., Uozumi, N., Schroeder, J.I., and Crawford, N.M. 1995. Multiple genes, tissue specificity, and expression-dependent modulation contribute to the functional diversity of potassium channels in Arabidopsis thaliana. Plant Physiol. 109: 1093-1106.

Cheung, A.Y., Wang, H., and Wu, H.-M. 1995. A floral transmitting tissue-specific glycoprotein attracts pollen tubes and stimulates their growth. Cell 82: 383-393.

Daram, P., Urbach, S., Gaymard, F., Sentenac, H., and Chérel, I. 1997. Tetramerization of the AKT1 plant potassium channel involves its C-terminal cytoplasmic domain. EMBO $\mathrm{I}$. 16: 3455-3463.

Derksen, J. 1996. Pollen tubes: A model system for plant cell growth. Bot. Acta 109: 341-345.

Dreyer, I., Horeau, C., Lemaillet, G., Zimmermann, S., Bush, D.R., Rodriguez-Navarro, A., Schachtman, D., Spalding, E.P., Sentenac, H., and Gaber, R.F. 1999. Identification and characterisation of plant transporters using heterologous expression systems. J. Exp. Bot. 50: 1073-1087.

Ehrhardt, T., Zimmermann, S., and Müller-Röber, B. 1997. Association of plant $\mathrm{K}_{\text {in }}{ }^{+}$channels is mediated by conserved C-termini and does not affect subunit assembly. FEBS Lett. 409: $166-170$.

Fan, L.-M., Wu, W.-H., and Yang, H.-Y. 1999. Identification and characterisation of the inward $\mathrm{K}^{+}$channel in the plasma membrane of Brassica pollen protoplasts. Plant Cell Physiol. 40: 859-865.

Fan, L.-M., Wang, Y.-F., Wang, H., and Wu, W.-H. 2001. In vitro Arabidopsis pollen germination and characterisation of the inward potassium currents in Arabidopsis pollen grain protoplasts. J. Exp. Bot. 52: 1603-1614.

Feijó, J.A., Sainhas, J., Holdaway-Clarke, T., Cordeiro, M.S., Kunkel, J.G., and Hepler, P.K. 2001. Cellular oscillations and the regulation of growth: The pollen tube paradigm. Bioessays 23: 86-94.

Franklin-Tong, V.E. 1999a. Signaling in pollination. Curr. Opin. Plant Biol. 2: 490-495.

- 1999b. Signaling and the modulation of pollen tube growth. Plant Cell 11: 727-738.

Gassmann, W. and Schroeder, J.I. 1994. Inward-rectifying $\mathrm{K}^{+}$ channels in root hairs of wheat. Plant Physiol. 105: 13991408.

Gaymard, F., Cerutti, M., Horeau, C., Lemaillet, G., Urbach, S., Ravallec, M., Devauchelle, G., Sentenac, H., and Thibaud, J.-B. 1996. The baculovirus/insect cell system as an alternative to Xenopus oocytes. First characterization of the AKT1 $\mathrm{K}^{+}$channel from Arabidopsis thaliana. I. Biol. Chem. 271: 22863-22870.

Gaymard, F., Pilot, G., Lacombe, B., Bouchez, D., Bruneau, D., Boucherez, J., Michaux-Ferriere, N., Thibaud, J.-B., and Sentenac, H. 1998. Identification and disruption of a plant Shaker-like outward channel involved in $\mathrm{K}^{+}$release into the xylem sap. Cell 94: 647-655.

Gilliland, L.U, McKinney, E.C., Asmussen, M.A., and Meagher, B.M. 1998. Detection of deleterious genotypes in multigenerational studies. I. Disruptions in individual Arabidopsis actin genes. Genetics 149: 717-725.
Hamill, O.P., Marty, A., Neher, E., Sakmann, B., and Sigworth, F.J. 1981. Improved patch-clamp techniques for high-resolution current recording from cells and cell-free membrane patches. Pflügers Arch. 391: 85-100.

Hirsch, R.E., Lewis, B.D., Spalding, E.P., and Sussman, M.R. 1998. A role for the AKT1 potassium channel in plant nutrition. Science 280: 918-921.

Höfgen, R. and Willmitzer, L. 1988. Storage of competent cells for Agrobacterium transformation. Nucleic Acids Res. 16: 9877.

Holdaway-Clarke, T.L., Feijó, J.A., Hackett, G.R., Kunkel, J.G., and Hepler, P.K. 1997. Pollen tube growth and the intracellular cytosolic calcium gradient oscillate in phase while extracellular calcium influx is delayed. Plant Cell 9: 1999-2010.

Hoth, S. and Hedrich, R. 1999. Distinct molecular bases for $\mathrm{pH}$ sensitivity of the guard cell $\mathrm{K}^{+}$channels KST1 and KAT1. $J$. Biol. Chem. 274: 11599-11603.

Hoth, S., Dreyer, I., Dietrich, P., Becker, D., Müller-Röber, B., and Heidrich, R. 1997. Molecular basis of plant-specific acid activation of $\mathrm{K}^{+}$uptake channels. Proc. Natl. Acad. Sci. 94: 4806-4810.

Jan, L.Y. and Jan, Y.N. 1992. Tracing the roots of ion channels. Cell 69: 715-718.

. 1997. Cloned potassium channels from eukaryotes and prokaryotes. Annu. Rev. Neurosci. 20: 91-123.

Lacombe, B., Pilot, G., Michard, E., Gaymard, F., Sentenac, H., and Thibaud, J.-B. 2000. A Shaker-like $\mathrm{K}^{+}$channel with weak rectification is expressed in both source and sink phloem tissues of Arabidopsis. Plant Cell 12: 837-851.

Lagarde, D., Basset, M., Lepetit, M., Conejero, G., Gaymard, F., Astruc, S., and Grignon, C. 1996. Tissue-specific expression of Arabidopsis AKT1 gene is consistent with a role in $\mathrm{K}^{+}$ nutrition. Plant J. 9: 195-203.

Li, H., Lin, Y., Heath, R.M., Zhu, M.X., and Yang, Z. 1999. Control of pollen tube tip growth by a Rop GTPase-dependent pathway that leads to tip-localized calcium influx. Plant Cell 11: 1731-1742.

Lobréaux, S. and Briat, J.-F. 1991. Ferritin accumulation and degradation in different organs of pea (Pisum sativum) during development. Biochem. J. 274: 601-606.

Lord, E. 2000. Adhesion and cell movement during pollination: Cherchez la femme. Trends Plant Sci. 5: 368-372.

MacKinnon, R. 1991. Determination of the subunit stoichiometry of a voltage-activated potassium channel. Nature 350: $232-235$.

Mansfield, S.G. and Briarty, L.G. 1991. Early embryogenesis in Arabidospis thaliana. II. The developing embryo. Can. J. Bot. 69: 461-476.

Mäser, P., Thomine, S., Schroeder, J.I., Ward, J.M., Hirschi, K., Sze, H., Talke, I.N., Amtmann, A., Maathuis, F.J., Sanders, D., et al. 2001. Phylogenetic relationships within cation transporter families of Arabidopsis. Plant Physiol. 126: $1646-1667$.

Messerli, M.A., Danuser, G., and Robinson, K.R. 1999. Pulsatile influxes of $\mathrm{H}^{+}, \mathrm{K}^{+}$and $\mathrm{Ca}^{2+}$ lag growth of Lilium longiflorum pollen tubes. J. Cell Sci. 112: 1497-1509.

Messerli, M.A., Créton, R., Jaffe, L.F., and Robinson, K.R. 2000. Periodic increases in elongation rate precede increases in cytosolic $\mathrm{Ca}^{2+}$ during pollen tube growth. Dev. Biol. 222: 84-98.

Moutinho, A., Trewavas, A.J., and Malhó, R. 1998. Relocation of a $\mathrm{Ca}^{2+}$-dependent protein kinase activity during pollen tube reorientation. Plant Cell 10: 1499-1510.

Müller-Röber, B., Ellenberg, J., Provart, N., Willmitzer, L., Bush, H., Becker, D., Dietrich, P., Hoth, S., and Hedrich, R. 1995. Cloning and electrophysiological analysis of KST1, an in- 
ward rectifying $\mathrm{K}^{+}$channel expressed in potato guard cells. EMBO J. 14: 2409-2416.

Obermeyer, G. and Blatt, M.R. 1995. Electrical properties of intact pollen grains in Lillium longiflorum: Characteristics of the non germinating pollen grain. J. Exp. Bot. 46: 803-813.

Obermeyer, G. and Kolb, H.-A. 1993. $\mathrm{K}^{+}$channels in the plasma membrane of lily pollen protoplasts. Bot. Acta 106: 26-31.

Pierson, E.S., Miller, D.D., Callaham, D.A., Shipley, A.M., Rivers, B.A., Cresti, M., and Hepler, P.K. 1994. Pollen tube growth is coupled to the extracellular calcium ion flux and the intracellular calcium gradient: Effect of BAPTA-type buffers and hypertonic media. Plant Cell 6: 1815-1828.

Reyes, R., Duprat, F., Lesage, F., Fink, M., Salinas, M., Farman, N., and Lazdunski, M. 1998. Cloning and expression of a novel $\mathrm{pH}$-sensitive two pore domain $\mathrm{K}^{+}$channel from human kidney. J. Biol. Chem. 273: 30863-30869.

Sari-Gorla, M. and Frova, C. 1997. Pollen tube growth and pollen selection. In Pollen biotechnology for crop production and improvement (eds. K.R. Shivanna and V.K. Sawhney), pp. 333-351. Cambridge University Press, Cambridge, UK.

Schiefelbein, J., Galway, M., Masucci, J., and Ford, S. 1993. Pollen tube and root-hair tip growth is disrupted in a mutant of Arabidopsis thaliana. Plant Physiol. 103: 979-985.

Schopfer, C.R., Nasrallah, M.E., and Nasrallah, J.B. 1999. The male determinant of self-incompatibility in Brassica. Science 286: 1697-1700.

Sentenac, H., Bonneaud, N., Minet, M., Lacroute, F., Salmon, J.M., Gaymard, F., and Grignon, C. 1992. Cloning and expression in yeast of a plant potassium ion transport system. Science 256: 663-665.

Snape, J.W. and Lawrence, M.J. 1971. The breading system of Arabidopsis thaliana. Heredity 27: 299-302.

Stadler, R., Truernit, E., Gahrtz, M., and Sauer, N. 1999. The AtSUC1 sucrose carrier may represent the osmotic driving force for anther dehiscence and pollen tube growth in Arabidopsis. Plant J. 19: 269-278.

Takasaki, T., Hatakeyama, K., Suzuki, G., Watanabe, M., Isogai, A., and Hinata, K. 2000. The $\mathrm{S}$ receptor kinase determines self-incompatibility in Brassica stigma. Nature 403: 913-916.

Taylor, L.P. and Hepler, P.K. 1997. Pollen germination and tube growth. Annu. Rev. Plant Physiol. Plant Mol. Biol. 48: 461491.

Thorsness, M.K., Kandasamy, M.K., Nasrallah, M.E., and Nasrallah, J.B. 1993. Genetic ablation of floral cells in Arabidopsis. Plant Cell 5: 253-261.

Véry, A.-A., Bosseux, C., Gaymard, F., Sentenac, H., and Thibaud, J.-B. 1994. Level of expression in Xenopus oocytes affects some characteristics of a plant inward-rectifying voltage-gated $\mathrm{K}^{+}$channel. Pflügers Arch. 428: 422-424.

Véry, A.-A., Gaymard, F., Bosseux, C., Sentenac, H., and Thibaud, J.-B. 1995. Expression of a cloned plant $\mathrm{K}^{+}$channel in Xenopus oocytes: Analyses of macroscopic currents. Plant J. 7: 321-332.

Weisenseel, M.H. and Jaffe, L.F. 1976. The major growth current through lily pollen tubes enters as $\mathrm{K}^{+}$and leaves as $\mathrm{H}^{+}$. Planta 133: 1-7.

Weisenseel, M.H. and Wenisch, H.H. 1980. The membrane potential of growing lily pollen. Z. Pflanzenphysiol. 99S: 313323.

White, P.J. 1997. Cation channels in the plasma membrane of rye roots. J. Exp. Bot. 48: 449-514.

Wilhelmi, L.K. and Preuss, D. 1999. The mating game: Pollination and fertilization in flowering plants. Curr. Opin. Plant Biol. 2: 18-22.

Wolters-Arts, M., Lush, W.M., and Mariani, C. 1998. Lipids are required for directional pollen-tube growth. Nature 392: 818-821.

Yang, Z. 1998. Signaling tip growth in plants. Curr. Opin. Plant Biol. 1: 525-530.

Zimmermann, S. and Sentenac, H. 1999. Plant ion channels: From molecular structures to physiological functions. Curr. Opin. Plant Biol. 2: 477-482. 


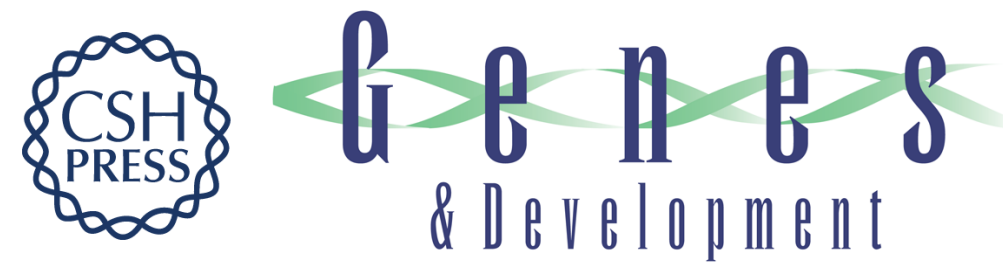

\section{Pollen tube development and competitive ability are impaired by disruption of a Shaker $\mathrm{K}^{+}$channel in Arabidopsis}

Karine Mouline, Anne-Aliénor Véry, Frédéric Gaymard, et al.

Genes Dev. 2002, 16:

Access the most recent version at doi:10.1101/gad.213902

References This article cites 61 articles, 21 of which can be accessed free at: http://genesdev.cshlp.org/content/16/3/339.full.htmI\#ref-list-1

License

Email Alerting

Receive free email alerts when new articles cite this article - sign up in the box at the top Service right corner of the article or click here.

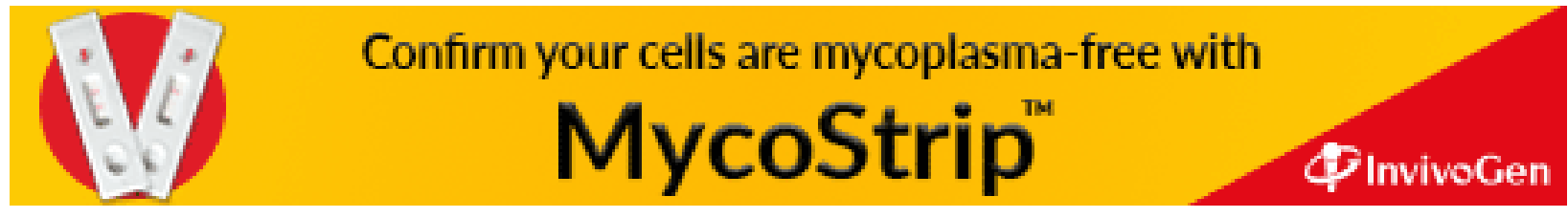

